\title{
Wat
}

\section{plus inflacja (w humanistyce)}

\section{Recenzja książki Marty Baron-Milian, Wat plus Vat. Związki literatury i ekonomii w twórczości Aleksandra Wata, Uniwersytet Śląski, Oficyna Wydawnicza Wacław Walasek, Katowice 2015, ss. 287.}

Inwencja powinna obwieścić samą siebie jako odkrycie tego, co nie wydaje się możliwe, bez czego ograniczałaby się ona do ujawniania programu tego, co możliwe, w ekonomii tego samego.

Jacques Derrida ${ }^{1}$

Tym, co elektryzuje uwagę czytelnika biorącego do ręki książkę Marty Baron-Milian jest jej tytuł, efektownie i intrygująco wykorzystujący homofonię nazwiska Aleksandra Wata i powszechnie przyjętej nazwy podatku od wartości dodanej. Co prawda Vat do Wata nie całkiem chronologicznie przystaje (podatek ten został stworzony i wprowadzony dopiero po II wojnie światowej), ale pożytek z kalamburu ma zdecydowanie wykraczać poza retoryczne efekty. Zdaniem autorki badanie „związków literatury i ekonomii w twórczości Aleksandra Wata" pozwala spojrzeć na tę twórczość z nowej, szerszej perspektywy, ukazuje niesłusznie pomijaną przez badaczy „nadzwyczajną predylekcję pisarza do ekonomicznego czy materialistycznego sposobu myślenia o własnym życiu, rzeczywistości i literaturze" (s. 13) i umożliwia wyprowadzenie interpretacji jego wierszy "poza ciasne ramy poezji metafizycznej” (s. 139). Zastosowanie "klucza ekonomicznego" (s. 12) ma być - mówiąc inaczej i nawiązując do cytatu z Derridy, którym posłużyłem się jako mottem - cenną „inwencją", umożliwiającą „odkrycia”, które z perspektywy ujęć utrwalonych w recepcji Wata "nie wydają się możliwe”.

Książka składa się z trzech niebanalnie zatytułowanych części: Literacka historia ekonomii, ekonomiczna historia literatury - Bogu ducha winny. Ekonomia,

* Uniwersytet Jana Kochanowskiego w Kielcach, Instytut Filologii Polskiej, Zakład Historii Literatury i Teorii Literatury, e-mail: aster.pietrych@gmail.com.

${ }^{1}$ J. Derrida, Psyché. Odkrywanie innego, przeł. M. P. Markowski, [w:] Postmodernizm. Antologia przekładów, oprac. R. Nycz, Kraków 1997, s. 104. 
teologia, nowoczesność - Przygody ciała, znaków i pieniędzy. Transakcje Aleksandra Wata, a swoje rozważania autorka buduje w oparciu o koncepcje takich autorów jak Walter Benjamin, Pierre Bourdieu, Jacques Derrida, Michel Foucault, Martin Heidegger, Julia Kristeva, Jacques Lacan czy Michał Paweł Markowski. Koniecznie trzeba też tu wymienić Jochena Hörischa, autora książki Orzeł czy reszka. Poezja pieniądza, książki dla polskiej badaczki niezwykle ważnej, często w jej pracy przywoływanej, referowanej i cytowanej.

Fascynacja Hörischem daje niekiedy dwuznaczne efekty. Na przykład jednym z argumentów za tezą, że w wierszu Buchalteria Wat ukazuje w syntetycznym skrócie nie tylko własne życiowe doświadczenia, ale także istotę "rachującej nowoczesności”, ma być przejęta od Hörischa gra słów zählen $i$ erzählen sugerująca bliskość „liczenia” i „opowiadania” - gra słów niemieckich, która nie ma odpowiednika w języku polskim, co jednak autorka uznaje za kwestię drugorzędną (zob. s. 172²); w książce Baron-Milian wskazać można nawet niejawną parafrazę fragmentu z książki niemieckiego literaturoznawcy ${ }^{3}$.

Te przykłady zbyt daleko idącego zafascynowania Hörischem potraktować wypada jako swego rodzaju sygnały ostrzegawcze: jakkolwiek książka Baron-Milian prezentuje się efektownie, to jednak ostatecznie budzi zdecydowanie więcej wątpliwości niż intelektualnej radości.

Zacząć trzeba od wrażenia ogólnego: sprawność, z jaką autorka posługuje się językiem współczesnej humanistyki, bazując na autorach będących en vogue (wyrażenia en vogue używam tu oczywiście z intencją krytyczną, ale w jakiejś mierze autorka sama je podsuwa, określając esej Heideggera o Hölderlinie jako po prostu „kultowy”, s. 253) w dzisiejszym dyskursie akademickim, jest tak duża, że jej rozważania przypominają nierzadko swego rodzaju retoryczną maszynę, której działanie teksty Wata jedynie inicjują, spełniając zaledwie rolę pretekstu, i której funkcjonowanie może ilustrować derridiańską ideę dyseminacji czy, jak to się niekiedy spolszcza, "plenienia się" znaków i sensów. Autorka tej cechy swoich rozważań jest w jakimś stopniu chyba świadoma, stwierdza (usprawiedliwiająco?) we wstępie „otwarcie ekonomicznej perspektywy otworzyło zarazem niekończącą się cyrkulację znaków i sensów, którą trudno było powstrzymać” (s. 33). I rzeczywiście, już pierwszy rozdział pierwszej części, nomen omen zatytułowany: Nadmuchane znaki. Inflacja i literatura, pokazuje, że autorka ma kłopot z panowaniem nad "cyrkulacją znaków i sensów”. Ten obszerny, liczący ponad 50 stron tekst to swoisty (by nie rzec - „nadmuchany”) komentarz do kilkuzdaniowej wzmianki Wata ze Wspomnień o futuryzmie (1930), wiążącej przemiany poetyki futurystów z inflacją, wzmianki notabene dla samego autora Wspomnień pobocznej - pojawia się w nawiasie (P 144-1454).

${ }^{2}$ Por. J. Hörisch, Orzeł czy reszka. Poezja pieniądza, przeł. J. Kita-Huber, S. Huber, Kraków 2010, s. 325.

${ }^{3}$ Zob. wykorzystanie cytatu z Pochodni w uchu Eliasa Canettiego, s. 62-63 - por. Hörisch, Orzet czy reszka, s. 16 .

4 Tak odsyłam do: A. Wat, Publicystyka, oprac. P. Pietrych, Warszawa 2008. 
Jednak to, że "cyrkulacja znaków i sensów” bywa momentami wyraźnie już „inflacyjna", nie jest jedynym ani nawet najważniejszym zastrzeżeniem, jakie omawiana książka budzi.

Zasadniczy problem, z którym zmaga się jej czytelnik, to kłopot z odpowiedzią na pytanie, co właściwie jest tu przedmiotem rozważań, ponieważ przedmiot ten nie został, wbrew pozorom stwarzanym chociażby przez tytuł, klarownie wyodrębniony. Wynika to z elementarnego, ciążącego nad całą książką zaniedbania: autorka nie precyzuje znaczenia kluczowego dla niej słowa „ekonomia”. We współczesnej polszczyźnie, i nie tylko w polszczyźnie, „ekonomia” bywa zazwyczaj utożsamiana z „ekonomią polityczną" - „nauką o prawach rządzących produkcją, wymianą i rozdzialem dóbr w społeczeństwie" ${ }^{\prime 5}$, nauką, której powstanie datuje się na początek XIX wieku i do rozwoju której walnie przyczynił się Karol Marks. Takie znaczenie słowa „ekonomia” jest dla Baron-Milian najwyraźniej zasadnicze i przez nią preferowane, choć oczywiście z pewnym nieuchronnym, i zrozumiałym przy zastosowaniu do literatury, rozluźnieniem semantycznych rygorów: chodzi już nie tylko o twierdzenia aspirujące do naukowości, ale o wszelkiego rodzaju obserwacje i informacje, które, niezależnie od intencji autora, da się wydobyć z jego utworów, i które odnoszą się do owych „praw rządzących produkcją, wymianą i rozdziałem dóbr w społeczeństwie". Na takie znaczenie „ekonomii” wskazuje zarówno umieszczenie w tytule Vatu, powracające w całej książce przekonanie, że u Wata „opowiadanie o sobie jest opowiadaniem "pod dyktando" systemu ekonomicznego" (s. 29), jak i wiele poszczególnych uwag analitycznych i interpretacyjnych, na przykład polemika z interpretacją wiersza Buchalteria dokonaną przez Mariana Stalę, któremu autorka zarzuca metaforyczne jedynie potraktowanie pojawiającego się $\mathrm{w}$ tym utworze słownictwa związanego $\mathrm{z}$ buchalteryjnym rachunkiem ekonomicznym, podczas gdy jej zdaniem, wyartykułowanym za pomoca zasadniczej tezy Filozofii pieniadza Georga Simmela, wskazuje ono na "rachującą istotę nowoczesności” (s. 164).

Jednak wystarczy zajrzeć do słownika Doroszewskiego, aby się przekonać, że utożsamienie „ekonomii" z ekonomią polityczną to nie jedyne możliwe użycie tego słowa, że ma ono także znaczenie inne, bardziej ogólne, w dodatku dawniej - dominujące: „umiejętność gospodarowania, racjonalnego użytkowania czego; gospodarność; oszczędność"6. To ogólne znaczenie, wywodzące się z greckiego oikonomia przez wieki w kulturze europejskiej dominowało, stając się, co więcej, podstawą ważkich pojęć i metafor. Na przykład w chrześcijańskiej teologii, w której rozważano problem "ekonomii zbawienia” czy „boskiej ekonomii"; przypomina tu się oczywiście wiersz Czesława Miłosza Oeconomia divina, do tego znaczenia odsyła też sam Wat, gdy w wierszu Ciemne świecidło pisze o Astrologu, który "trutynuje”, czyli rozważa koniunkcję gwiazd z "Oekonomią bied i brzydot". Warto zauważyć, że do tego ogólnego, tradycyjnego znaczenia odsyła też użycie słowa „ekonomia” we wstępnym cytacie z Derridy, gdzie

\footnotetext{
${ }^{5}$ Stownik języka polskiego, red. W. Doroszewski, Warszawa 1965, t. 2: D-G, s. 664.

${ }^{6}$ Tamże.
} 
najwyraźniej oznacza ono gospodarowaniem zbiorem pojęć i retorycznych chwytów, z których konstruowany jest dyskurs. Przykłady te pokazują funkcjonowanie słowa „ekonomia” poza jakimkolwiek związkiem z ekonomią polityczną, czyli, odwołując się do tytułu omawianej książki, poza jakimkolwiek związkiem z Vatem.

Baron-Milian trudno odmówić erudycji, przywołuje zarówno uwagi o oikonomos w Polityce Arystotelesa (s. 254), jak i chrześcijańskie pojęcie „ekonomii zbawienia" (s. 238) - a jednak kwestią wieloznaczności słowa „ekonomia" nigdzie się wprost nie zajmuje, wydaje się natomiast wierzyć, że da się prosto przejść od rozważań Arystotelesa i teologicznej „ekonomii zbawienia" do koncepcji Marksa i praw ekonomii politycznej (zob. s. 255). Co więcej, $z$ retorycznym rozmachem eksploruje rozległe pole konotacji, jakie otwierają różne znaczenia tego słowa: „ekonomia”, zdaniem autorki, obejmuje więc nie tylko wszystko to, co związane z "buchalterią", "lichwą" czy „procentem”, ale też wszystko to, co związane z "rachunkiem”, „winą", "długiem”, "karą" „odpłatą" czy „wymianą" (zob. zdumiewające wyliczenie s. 29).

W efekcie dyskurs Baron-Milian, naznaczony semantyczną mglistością kluczowego pojęcia, cechuje jednocześnie swoisty "panekonomizm”, którego narzędziem są łańcuchy sylogizmów prowadzących ostatecznie do wiązania wszystkiego ze sferą ekonomii politycznej.

Przykładem mogą tu być uwagi dotyczące zagadkowego wiersza Wata zatytułowanego Arytmetyka, mówiącego o towarzyszącym każdemu w każdej sytuacji alter ego? aniele stróżu? („Gdy jesteś sam, / nie ufaj, że jesteś sam. / On (ona) zawsze jest z tobą"). Arytmetyka, jak przyznaje autorka, jest dla niej utworem ważnym przede wszystkim ze względu na sam tytuł, ten bowiem pozwala przekształcić bardzo niejasne intuicje interpretacyjne („mamy niejasne przeczucie, [że] słowa nie mają tu pozytywnego, jasnego i ciepłego wydźwięku”, s. 127) w stwierdzenie, że chodzi o „rachunek sumienia czy sumowanie rachunku win”, co z kolei - poprzez „buchalteryjna metaforę [...] jedną z najważniejszych w twórczości Aleksandra Wata", którą autorka wywodzi z zawartego w tekstach syna obrazu ojca, Mendla Chwata - prowadzić ma do kwestii związanych z systemem ekonomicznym: koleje życiowe Mendla Chwata to dla Baron-Milian (wyjaskrawiającej wątki pojawiające się we wspomnieniach syna) dzieje nieudolnego przedsiębiorcy „próbującym radzić sobie z poczuciem dojmującego wyobcowania w kapitalistycznej rzeczywistości" (s. 128).

I trudno nawet powiedzieć, czy ma to być śmiała (nad)interpretacja wiersza Arytmetyka, czy też autorka konstruuje sobie tylko retoryczne przejście do rozdziału poświęconego relacjom Wata z ojcem. Pewne jest natomiast, że rachunek sumienia jest dla Baron-Milian zjawiskiem "ekonomicznym” - czy jak stwierdza w innym miejscu, "teologiczno-ekonomicznym" (s. 175) - tyle, że nie wiadomo, co to właściwie znaczy, co wspólnego ma, poza samym skojarzeniem z czynnością liczenia, rachunek sumienia $\mathrm{z}$ „rachującą istotą nowoczesności", o Vacie nie wspominając.

We wstępie omawianej książki znaleźć można ważną deklarację ideową. Baron-Milian uznaje, że „krytyka marksistowska, szkoła frankfurcka czy różnego typu lewicowe teorie krytyczne z I połowy XX wieku" stworzyły 
„potężne teoretyczne i filozoficzne zaplecze" (s. 15) dla interesującego ją problemu związków literatury i ekonomii. Aprobata koncepcji rozwijających Marksowski koncept homologii „bazy” $\mathrm{i}$ „nadbudowy” nie zaskakuję (choć kwestią, do której jeszcze trzeba będzie wrócić, jest ocena jakości, nazwijmy to tak, „marksizmu” Baron-Milian), w tym samym kręgu ideowym mieszczą się poglądy tak ważnego dla polskiej badaczki Jochena Hörischa. Ten ostatni jednak, warto zauważyć, niezależnie od tego jak oceniać precyzje i spójność prezentowanych przez niego analiz tekstów literackich, obrał za bohatera swojej książki "pieniądz”, które to pojęcie jest zdecydowanie bardziej niż „ekonomia" jednoznaczne, przynajmniej na poziomie słownika, i to zarówno słownika języka niemieckiego, jak polszczyzny. Natomiast wieloznaczność „ekonomii" powoduje, że rozważania zawarte w książce Wat plus Vat nieuchronnie i właściwie nieustannie oscylują między orzekaniem homologii odsyłającej do światopoglądowych założeń marksizmu a wskazywaniem na analogię, której źródłem może być nie tyle nawet podobieństwo między różnymi sferami rzeczywistości, ile językowa inwencja w ich opisie. I choć Baron-Milian, nie tylko przy okazji polemiki ze Stalą, deklaruje niechęć do traktowania "ekonomicznego" słownika jako jedynie „rodzaju metaforycznego sztafażu” (s. 179), na poziomie takiego sztafażu niejednokrotnie w swoich rozważaniach pozostaje.

Semantyczna elastyczność metafor bywa, jak wiadomo, właściwie nieograniczona. Można więc, na przykład, konstruując na bazie analogii śmiałą metaforę, ująć funkcjonowanie literatury w rzeczywistości społecznej na wzór funkcjonowania pieniądza jako środka (czy jak powiedziałaby Baron-Milian idąc tu za terminologią Hörischa - medium) wymiany i powiedzieć, że literatura służy Watowi do „wymiany cielesnego doświadczenia na znaki czy - lepiej - zbycia ciała na rynku znaków" (s. 251). Można tak rzecz sformułować, tyle że, po pierwsze, są to określenia ewidentnie metaforyczne, zwłaszcza owo „zbywanie ciał na rynku znaków” żadnym sposobem nie da się rozumieć dosłownie, po drugie - lektura rozdziału, z którego zaczerpnąłem powyższy cytat, nie pozostawia wątpliwości, że $\mathrm{w}$ ten sposób pseudonimowane są problemy, które we współczesnym literaturoznawstwie były już niejednokrotnie rozważane: problem (nie)wyrażalności i idiomatyczności indywidualnego doświadczenia czy generalny problem reprezentacji, i narzuca się pytanie, czy warto te kwestie ujmować za pomocą takich akurat metafor, czy daje to jakiś - nie bójmy się tego „ekonomicznego" słowa - zysk (poznawczy).

W zakończeniu swojej książki Baron-Milian deklaruje: „Najważniejsze w lekturze twórczości Aleksandra Wata przez pryzmat najszerzej pojętej ekonomii było dla mnie ciągłe kierowanie się tam, gdzie wskazują z jednej strony same teksty, a z drugiej, biografia i historia, w wyjątkowy sposób przecież w twórczości Wata »utekstowione«" (s. 269). Ta deklaracja respektu wobec autora i jego utworów brzmi szlachetnie - tyle że w omawianej książce jest po prostu niewiarygodna.

I to nawet nie dlatego, że niejako przy okazji zacytowane zdanie jedynie umacnia wrażenie, że „ekonomia” jest w książce Baron-Milian pojęciem mglistym i trudno uchwytnym - nie wiadomo bowiem, co ma wspólnego 
ekonomia "najszerzej pojęta” z tytułowym Vatem, czy aprobowaną przez autorkę postawą „krytyki marksistowskiej”. Ale końcowej deklaracji przede wszystkim zaprzecza inna cecha zbudowanego przez Baron-Milian dyskursu, ostatecznie zdecydowanie bardziej niż mgławicowość „ekonomii” motywująca jego negatywną ocenę - chodzi o deficyty warsztatowej rzetelności, w tym szczególnie trudno akceptowalny brak lojalności wobec bohatera książki.

Zacznijmy od kwestii stosunkowo prostej: błędów w datowaniu. W książce Wat plus Vat bez trudu można je wskazać, poczynając od stosunkowo „niewinnych” (Wat nie został redaktorem naczelnym „Miesięcznika Literackiego" w 1930 roku - zob. s. 92 - ale był nim od początku ukazywania się pisma, czyli od roku 1929; rozmowy Wata z Miłoszem, które potem stały się podstawą Mojego wieku, nie odbyły się „na początku lat sześćdziesiątych", s. 27, ale w połowie dekady), poprzez zdecydowanie poważniejsze (na s. 142 autorka wprowadza cytat z Wata stwierdzeniem "niemal u progu swojego życia napisze" - po czym następuje przytoczenie fragmentu z Moraliów, które powstały, gdy Wat miał już ponad 50 lat; notabene być może $w$ kontekście tego lapsusu widzieć trzeba tajemniczą wzmiankę ze Wstępu o "druzgocącej krytyce" marksizmu, jaką Wat miał przeprowadzić „w swych szkicach u progu życia”, s. 27) do dziwacznych (na s. 88 pojawia się wzmianka o "małych prozach z tomu z 1931 roku”, którego bibliografia Wata nie zna, kontekst pozwala się domyśleć, że mowa po prostu o Bezrobotnym Lucyferze, wydanym w poprzedniej dekadzie, czego autorka jest, $\mathrm{w}$ innym miejscu, świadoma, zob. s. 91, ten błąd w datowaniu wydaje się jednak o tyle nieprzypadkowy, że sygnalizuje jej skłonności, nad którą nie do końca udaje się zapanować, aby, wbrew biograficznym faktom, opowiadania z lat dwudziestych umieszczać po okresie marksistowskim Wata, taka kolejność, sugerowana już przez kompozycję pierwszej części książki, zostaje właściwie wprost wyartykułowana w jej Zakończeniu, zob. s. 270). Z Bezrobotnym Lucyferem związana jest też inna, bardziej zasadnicza kwestia, którą potraktować trzeba jako objaw niezrozumiałej filologicznej lekkomyślności: choć opowiadania Wata z lat dwudziestych są dla Baron-Milian jednymi z najważniejszych jego dzieł, omawia je i cytuje na podstawie wydania z 1960 roku, wydania, które jest niekompletne (dwa utwory okazały się w PRL-u niecenzuralne) i w którym Wat wprowadził zmiany "tak poważne, że nie sposób ich traktować jedynie jako nowej autorskiej adiustacji tekstu. W pewnym sensie Wat ponownie napisał swoje nowele [...]"7.

Oczywiście drobne błędy, choć należy ich unikać, mogą się przydarzyć każdemu. Jednak, jak widać, w omawianej książce nie zawsze są one drobne, w dodatku sygnalizują znaczącą cechę postawy Baron-Milian: zadziwiająco słabe zainteresowanie kontekstami historycznymi, a zwłaszcza historycznoliterackimi, i to mimo deklarowanego uznania dla „metod historycznych" (s. 23).

${ }^{7}$ W. Bolecki, Odmiany tekstu, [w:] A. Wat, Bezrobotny Lucyfer i inne opowieści, oprac. W. Bolecki i J. Zieliński, Warszawa 1993, s. 237. 
Wręcz symboliczny jest $\mathrm{w}$ tym względzie początek rozdziału poświęconego Bezrobotnemu Lucyferowi: Baron-Milian otwiera go obrazem Wata piszącego w 1927 roku Żyda Wiecznego Tułacza, najważniejsze dla niej opowiadanie $\mathrm{z}$ tego zbioru, piszącego przy oknie, co pozwala mu odbierać „„»znaki ulicy« - znamiona nowoczesności” (s. 91). Ten ostatni element jest kluczowy, odsyła do ambicji autorki, aby pokazać Wata jako autora otwartego na obserwacje i doświadczenia, których dostarcza rzeczywistość, oczywiście przede wszystkim w jej aspekcie ekonomicznym - tworzącego przecież, wedle cytowanego już określenia, „"pod dyktando « systemu ekonomicznego". W zbudowanym przez Baron-Milian obrazie kryje się jednak zasadniczy paradoks: o więzi swojego bohatera z rzeczywistością autorka mówi za pomocą czystej fikcji. Jej sygnałem jest kolejna błędna data: Żyda Wiecznego Tułacza Wat w 1927 roku nie pisał, bo go już napisał i to na tyle dawno, że opowiadanie ukazało się rok wcześniej w "Skamandrze” (1926, z. XLVII-XLVIII), "1927" nie jest zresztą datą ścisłą nawet w odniesieniu do wydania Bezrobotnego Lucyfera, jak bowiem opowiadał potem Wat Miłoszowi, tom jego opowiadań ukazał się, antydatowany, już pod koniec 1926 roku (MW I 72). Jest to faktograficzna wiedza łatwo dostępna, jednak przez Baron-Milian nonszalancko ignorowana, podobnie jak ignoruje ona, wierna stworzonemu przez siebie obrazowi autora zasłuchanego $\mathrm{w}$ "znaki ulicy", intertekstualny aspekt Bezrobotnego Lucyfera. Dla pierwszych czytelników opowiadań Wata oczywiste było podobieństwo zawartego w nich "brawurowego ataku na współczesność" ${ }^{8}$ do tego, co znaleźć było wtedy można u głośnych i modnych pisarzy, takich jak Gilbert Keith Chesterton czy Ilja Erenburg, pisarzy czytywanych niewątpliwie także przez Wata (o pierwszym pisał wtedy parokrotnie, drugiego tłumaczył). Zestawianie Wata z Chestertonem i Erenburgiem stanowiło właściwie leitmotiv recenzji Bezrobotnego Lucyfera, które ukazały się w latach 20.; wątek ten jest jednak dla Baron-Milian do tego stopnia nieinteresujący, że nazwiska obu pisarzy w ogóle się w jej książce nie pojawiają. Zignorowanie kwestii wewnątrzliterackich inspiracji akurat $\mathrm{w}$ książce o Wacie uznać trzeba za błąd elementarny, autorka sprzeniewierza się w ten sposób własnym deklaracjom, że kierunki jej analiz wyznaczają teksty Wata i jego biografia: Wat był - wykorzystuję tu określenie, którego użył w odniesieniu do Zygmunta Krasińskiego, autora fascynującego go również ze względu na to podobieństwo - pisarzem, który „przyszedł do literatury z literatury” (P 731), i rola tego, co déjà lu jest $\mathrm{w}$ jego twórczości co najmniej niebagatelna, by nie rzec - zasadnicza. Niewątpliwie uwzględnienie wymiaru intertekstualnego utworów Wata komplikowałoby opis jego twórczości jako powstającej ","pod dyktando « systemu ekonomicznego", trudno to jednak uznać za jakiekolwiek usprawiedliwienie. Skądinąd niechęć autorki do kwestii intertekstualnych ma swój zaskakujący rewers: obraz Wata piszącego w 1927 roku Żyda Wiecznego Tułacza nie został zbudowany w oparciu o historycznoliteracką wiedzę (jakkolwiek by nie oceniać jej rzetelności), ale jest wytworem... relacji

${ }^{8}$ Określenie z recenzji Leona Pomirowskiego, „Bezrobotny Lucyfer" Wata, „Wiadomości Literackie" 1927 nr 10, 6 III, s. 3. 
intertekstualnej, czego zresztą autorka nie kryje, otwarcie wywodząc ten obraz z eseju Agaty Bielik-Robson poświęconego Marshallowi Bermanowi ${ }^{9}$.

Retoryka dominuje w książce Baron-Milian nad historycznymi i historycznoliterackimi konkretami. Niekiedy służy ujednoznacznieniu tego, co jednoznaczne nie jest. Tak ma się rzecz na przykład z arcyważnym dla Baron-Milian passusem ze Wspomnień o futuryzmie, w którym Wat wiąże ewolucję metafory w twórczości futurystów z inflacją:

Inflacja była wówczas formą widzenia rzeczy. Miernik rzeczy zatracił swoją stałość, skakał wraz ze skokami waluty. Prawo tożsamości przestało obowiązywać. Rzecz przestała być sobą. Nazajutrz już nie była tym, czym była poprzedniego dnia. Inflacja rozrywała identyczność rzeczy ze sobą (P 144-145).

Autorka, dla której jest to „perełka” (s. 116) w publicystyce redaktora „Miesięcznika Literackiego", dostrzega w tych zdaniach „odkrywcze” obserwacje i szczegółowo je opisuje (s. 80-81) - dając opis, który nieodparcie przywodzi na myśl idee głośnie w humanistyce kilkadziesiąt lat później: pogląd, że każdy system znaków związany jest z władzą (vide Foucault), koncepcję wedle której inflacja, podważając zaufanie do pieniądza, który ma charakter znakowy, podważa tym samym zaufanie do wszelkich systemów znakowych (vide ontosemiologia pieniądza Hörischa), przekonanie o „płynnym” charakterze nowoczesności (vide obraz nowoczesności w pisarstwie Bermana). Pozostaje kwestią wielce dyskusyjną, czy to wszystko zdania sformułowane przez Wata znaczą, czy też są to znaczenia wpisane w nie przez badaczkę, która czytała i ceni Foucaulta, Hörischa i Bermana. Interpretacji Baron-Milian przeciwstawić można próbę ustabilizowania sensów „,perełki” Wata przez odniesienie do historycznych świadectw lektury: w 1930 roku Irzykowski w artykule o znamiennym tytule Piła marksistyczna uznał ten passus ze Wspomnień o futuryzmie za zbiór dogmatycznych frazesów, które zastępują pisarzom deklarującym akces do marksizmu rzetelny namysł na rzeczywistością. Baron-Milian ocenę Irzykowskiego oczywiście odrzuca (niepotrzebne zresztą komplikując jej sedno, zob. s. 79), sama jednak przyznaje, że w okresie redagowania "Miesięcznika Literackiego” Wat bywał w swym ideologicznym dogmatyzmie bardziej papieski niż sam papież (odwołanie do, cokolwiek ekscentrycznego w tym kontekście, frazeologizmu to inspiracja zaczerpnięta z omawianej książki, zob. s. 73) i dogmatyczne frazesy dominują w "raczej nudnej, tendencyjnej, schematycznej” publicystyce „Miesięcznika” (s. 116). Warto też odnotować, że argumentem przeciw dopatrywaniu się w passusie ze Wspomnień szczególnej głębi jest zarówno status tego fragmentu (który, jak już pisałem, pojawia się w nawiasie, co sugeruje raczej odnotowanie oczywistości niż sygnalizowanie oryginalnych odkryć intelektualnych), a także to, że odpowiadając w Metamorfozach futuryzmu na zarzuty Irzykowskiego, Wat już zdecydowanie nie daje "perełki", ale frazesy:

${ }^{9}$ A. Bielik-Robson, Marks tańczacy, [przedmowa w:] M. Berman, Przygody z marksizmem, przeł. S. Szymański, Warszawa 2012, s. 7-8. 
Stwierdziłem, że futuryzm w swoim pierwszym okresie, prymitywistycznym, miał fizjonomię drobnomieszczańską z mocnym nalotem okresu inflacyjnego, przy czym przez inflację rozumiałem w danym wypadku nie, jak mi w sposób nieco humorystyczny wmawia pan Irzykowski, sam element gospodarczy, lecz psychoideologię środowiska socjalnego, uwarunkowaną inflacją. W związku z tym pisałem o antycywilizatorstwie i wsteczności pierwszego okresu futuryzmu, co nie wykluczało zresztą obecności w nim zalążków rewolucyjnych (P 164).

Retoryczne zdecydowanie pozwala Baron-Milian ujednoznacznić to, co dalekie od jednoznaczności, a niekiedy po prostu zastępuje argumenty i egzemplifikację. I tak na przykład w podsumowaniu uwag na temat bardzo ważnego dla niej wiersza Buchalteria pojawia się stwierdzenie, że wiersz ten ,jawi się jako ekonomiczno-teologiczny traktat, wokół którego orbitują dziesiątki innych tekstów Aleksandra Wata" (s. 169), autorka jednak nawet nie próbuje dookreślić zbioru utworów „orbitujących” wokół Buchalterii, a metaforyczność „orbitowania” praktycznie uniemożliwia takie dookreślenie czytelnikowi. Podobnie gołosłowne pozostaje stwierdzenie pojawiające się kilka stron dalej, że „rachowania jest u Wata na pęczki” (s. 175).

Co więcej, retoryka w książce Baron-Milian czasem nie tylko zastępuje argumenty, niekiedy ingeruje w sferę faktów nadając zamysłowi „ekonomizacji” Wata charakter konceptu uzasadnianego w sposób nieprzekonujący i pośpieszny, w efekcie - konceptu apriorycznego i tendencyjnie forsowanego. I tak na przykład jednym z argumentów, że głównym bohaterem Bezrobotnego Lucyfera jest... wolny rynek („po prostu”, s. 93) ma być zdanie „Na niebie gwiazda wieczorna była rozpięta jak plakat" (z opowiadania Czyście nie widzieli ulicy Gołębiej?), w którym wedle Baron-Milian Wat ujął "zjawisko kolonizacji świadomości i wyobraźni przez mechanizmy rynkowe” (s. 94). Dziwne skutki ma też zafascynowanie Baron-Milian hiperinflacją lat dwudziestych XX wieku. Pomijam już nawet to, że fascynacja ta owocuje całymi stronicami opisów doświadczenia inflacji u Benjamina, Canettiego i dadaistów, opisów wprowadzonych rozbrajająco otwartym przyznaniem, że nie mają bezpośredniego związku z Watem (zob. s. 50, 67); pomijam też to, że gdy autorka uznaje (cokolwiek samokrytycznie i nie do końca zgrabnie językowo), że trzeba „odbić się od dość wysokiego poziomu ogólności dotychczasowych rozważań, w który łatwo popaść" (s. 45) i należy przejść na "poziom doświadczenia”, jest to doświadczenie... niemieckie, choć powojenna inflacja dotknęła w pierwszej połowie lat dwudziestych również Polskę, co doprowadziło do znaczących niepokojów społecznych w 1923 roku (Wat wspomina o nich w Metamorfozach futuryzmu, zob. P 169), trudno tu oprzeć się podejrzeniu, że pisanie o inflacji w Niemczech jest jednak po prostu łatwiejsze, bo temat ma bogatą literaturę. Natomiast zdecydowanie oprotestować trzeba wyłaniający się z książki Baron-Milian obraz kontekstu historycznego początków twórczości Wata: dojmujące poczucie totalnego kryzysu kultury europejskiej, czyli, używając określeń autorki, poczucie upadku „wiary w moc wszelkich systemów znakowych i komunikacji symbolicznej” prezentowane jest jako efekt wyłącznie wydarzeń 
ekonomicznych, „inflacji, spekulacji, giełdowego krachu”, natomiast pomija się praktycznie milczeniem (na przykład na cytowanej tu stronie 25) wpływ na świadomość młodego Wata i współczesnych zarówno katastrofy Wielkiej Wojny (zob. na swój sposób oryginalny zarys genezy dadaizmu, w którym się o I wojnie światowej po prostu nie wspomina, s. 69), jak i rewolucji bolszewickiej w Rosji.

Niekiedy trudno zresztą oprzeć się wrażeniu, że autorka sama gubi się w meandrach własnej retoryki i metaforyki. Tu przykładem najbardziej ewidentnym jest wątek tajemniczy nawet dla czytelników zorientowanych w dziele Wata: „Stale pojawiające się w wierszach pisarza marzenie o transfuzjach i transplantacjach" (s. 12); marzenie to miałoby chyba wiązać z już wspomnianym dążeniem do „zbycia ciała na rynku znaków” (s. 251). O tym marzeniu autorka wspomina parokrotnie, daje nawet fragment zatytułowany Tkanki, transfuzje, transplantacje - w którym jednak nie pojawiają się dowody, że takie marzenie Wat rzeczywiście żywił, ale przywoływane są utwory, w których wyraźnie dochodzi do głosu niechęć do ciała, „pęd do cielesne autodestrukcji" (s. 243); spośród nich najistotniejszy okazuje się zaś wiersz Na wystawie Odillona Redona, w którym mowa o upuszczaniu krwi, aby wydestylować z niej „czystą / czarną / czern” - co o tyle ma to związek $\mathrm{z}$ "transfuzjami i transplantacjami”, że jest zaprzeczeniem tej pierwszej, jako to ujęła sama Baron-Milian w charakterystycznym dla siebie stylu, dochodzi w tym wierszu do odwrócenia "transfuzyjno-transplantacyjnej ekonomii ciała, która mogłaby przynieść medyczne o-calenie" (s. 244).

Ale niewątpliwie gorsza od sytuacji, gdy retoryka nie przystaje do faktów, jest sytuacja, gdy fakty są stwarzane na potrzeby retoryki i forsowanej tezy - a to się też $\mathrm{w}$ książce Baron-Milian zdarza. Jest rzeczą powszechnie znaną, że Wat miał dwuznaczny stosunek do polityki, naznaczony niechęcią, ale i fascynacją, o czym sam niejednokrotnie pisał. Nie jest natomiast rzeczą oczywistą „to, co polityczne ściśle i nierozerwalnie wiąże się u Wata z tym, co ekonomiczne", i że problematyką ekonomiczną Wat interesował się zwłaszcza pod koniec życia „w sposób szczególny” (s. 118). Aby tego dowieść, Baron-Milian twierdzi między innymi, że „Wat namiętnie czytał książki Johna Keynesa, wielokrotnie w swoich notatkach cytował ich fragmenty w różnych językach (najczęściej po francusku)" (s. 119) - i jest to po prostu stwierdzenie fałszywe: przywoływany przez autorkę $\mathrm{w}$ przypisie fragment z notatników Wata dowodzi jedynie, że Wat przeczytał w „Les Temps Modernes" artykuł słynnego ekonomisty (stąd cytaty z Keynesa po francuski - i tylko po francusku), co więcej, dwa wpisy na sąsiadujących kartkach notatnika to jedyne dowody zainteresowania Wata Keynesem nie tylko w ogromnym zbiorze jego notatek ( $\mathrm{w}$ wersji opublikowanej to tom ponad 900 -stronicowy ${ }^{10}$ ), ale $\mathrm{w}$ ogóle $\mathrm{w}$ jego tekstach. (Na marginesie odnotujmy jeszcze dwa inne zastrzeżenia do tego, co znajduje się stronie 119 omawianej książki: trudno zgodzić się z sugestią autorki, że już sama lektura słynnego pisma redagowanego przez Sartre’a dowodzi zainteresowań

${ }^{10}$ Zob. A. Wat, Notatniki, oprac. A. Dziadek, J. Zieliński, Warszawa 2015; notatki z lektury Keynesa s. 374, 377. 
Wata ekonomią; i kolejny lapsus chronologiczny, świadczący o nonszalancji, z jaką Baron-Milian traktuje faktograficzne szczegóły: artykuł Keynesa opublikowany został w „Les Temps Modernes" w 1961 roku, nie był to więc w życiu Wata czas "pobytu w Berkeley" - który przypadł na lata 1963-1965, czego zresztą autorka jest, w innym fragmencie swojej książki, świadoma, zob. s. 194).

Baron-Milian najbardziej jednak bulwersuje wtedy, gdy mimo deklaracji szacunku dla tekstów Wata i jego biografii, przystosowuje teksty i nawet biograficzne fakty do zakładanych tez, co nadaje niektórym jej interpretacjom posmak niestosownej manipulacji, otwierającej pole jedynie do "narcystyczno-liturgicznej erudycyjności”. Przywołuję tu określenia Jacka Leociaka z jego artykułu $O$ nadużyciach $w$ badaniach nad doświadczeniem Zagłady ${ }^{11}$, bo i w przypadku postmodernistycznego pisania o Holokauście, i w przypadku przesiąkniętej postmodernistyczną frazeologią książki Baron-Milian chodzi o ten sam elementarny i w gruncie rzeczy etyczny problem lojalności wobec doświadczeń, o których się pisze.

Przykładem rażącej nielojalności wobec Wata może być sposób, w jaki autorka komentuje wielkie odkrycie, którym dla niegdysiejszego redaktora "Miesięcznika Literackiego" było uchwycenie w czasie pobytu w moskiewskim więzieniu na Łubiance istoty "semantyki komunistycznej”: Wat dochodzi do wniosku, że terror stalinizmu oparty został na odrzuceniu "odwiecznego kryterium prawdy i fałszu”, na "totalnej alienacji - we wszystkich znaczeniach tego słowa - ludzkiej mowy" (MW II 4442). - Baron-Milian opatruje ten fragment "pamiętnika mówionego" następującym komentarzem:

\begin{abstract}
Wat zyskuje przekonanie o tym, że każda reprezentacja - choćby nie wiem jak zwodziła - jest polityczna, każda wymiana poddana jest manipulacjom władzy i mechanizmom symbolicznej przemocy, a każde przedstawienie stwarza alternatywną, autonomiczną rzeczywistość, której pretensje do adekwatności sankcjonowane mogą być jedynie przez władzę i należącą do niej powszechną miarę, stanowiącą prawo i dyktującą warunki wszelkiej wymiany (s. 223).
\end{abstract}

Komentarz to wątpliwy i co do meritum, i co do decorum. Polemizować można z twierdzeniem, że dopiero na Łubiance Wat odkrył polityczność wszelkich interpretacji rzeczywistości - przekonanie takie należy do żelaznego repertuaru założeń komunistycznej dogmatyki i oczywiście pojawiało się nieustająco w publicystyce "Miesięcznika”; zdecydowanie natomiast polemizować trzeba z supozycją uniwersalizacji, Wata nie interesowało bowiem $\mathrm{w}$ języku stalinizmu to, co w nim uniwersalne, charakterystyczne dla "każdej reprezentacji”, „wymiany”, "przedstawienia”,

${ }^{11}$ J. Leociak, O nadużyciach w badaniach nad doświadczeniem Zagłady, „Zagłada Żydów. Studia i Materiały" 2010, nr 6, s. 16.

${ }^{12}$ Tak odsyłam do: A. Wat, Mój wiek. Pamiętnik mówiony, rozmowy prowadził i przedmową opatrzył Cz. Miłosz, do druku przygotowała L. Ciołkoszowa, przypisy opracował R. Habielski, Warszawa 1998, t. 1-2; cyfra rzymska oznacza tom. 
a w samym stalinizmie to, co charakterystyczne dla „każdej” władzy przeciwnie, starał się on ukazać zbudowany pod hasłami marksizmu i komunizmu porządek porewolucyjnej Rosji, także porządek językowy, jako "nowy, istotnie od wszystkiego odmienny” („stalinizm, czyli komunizm zrealizowany, jest w swoim szczytowym momencie zjawiskiem w dziejach ludzkości nowym, istotnie od wszystkiego odmiennym", ŚNH 23513). Gorszy tu nie sam fakt, że Baron-Milian czyta Wata z dystansem do intencji pisarza, co samo w sobie nie jest oczywiście niczym nagannym i do czego piszącego te słowa akurat nie trzeba przekonywać; nie do przyjęcia jest jednak, że autorka prezentuje swoją skłonność do uogólnień i swoją interpretację jako interpretację Wata, nadając komentarzowi fałszywą modalność już otwierającym go stwierdzeniem "Wat zyskuje przekonanie”.

Ale jest tu jeszcze inny fałsz. Zamieniając dokonane na Łubiance odkrycie istoty „semantyki komunistyczne” na zgrabne, choć niezbyt oryginalne ogólniki z repertuaru postmodernistycznej humanistyki, Baron-Milian tym samym bierze $\mathrm{w}$ nawias to, co $\mathrm{w}$ opowieści Wata indywidualne, idiomatyczne, związane z jego biografią i konkretną sytuacją.

Dla Wata, zamkniętego w stalinowskim więzieniu, najważniejszy był nie abstrakcyjny i uniwersalny koncept, choćby najefektowniejszy, ale to, co z wiedzy o istocie stalinowskiej manipulacji semantyką wynikało dla nieustannie ponawianych prób zrozumienia własnej sytuacji i własnego doświadczenia życiowego; nieprzypadkowo cały fragment kończy się konkretnym i praktycznym wnioskiem: „Spory z komunistami są fikcją, trzeba patrzeć wyłącznie na ich ręce" (notabene choć Baron-Milian cytuje w tym miejscu obszerny fragment Mojego wieku, to zdanie pomija). Co więcej, nie tylko w opowieści Wata o pobycie na Łubiance, ale także w pisanych przez niego pod koniec życia szkicach sowietologicznych ten praktyczny aspekt rozważań jest szczególnie poruszający. Rewersem prób opisania i zinterpretowania fenomenu stalinizmu jest bowiem u Wata nieustające dążenie do nadania sensu, wagi, znaczenia własnemu doświadczeniu życiowemu, na które w decydujący sposób wpłynęło zetknięcie z komunizmem i stalinizmem. I jakkolwiek interpretacje Wata mogą się wydawać kontrowersyjne, gdy na przykład dostrzega w stalinizmie objawienie diabła w historii, poruszenie czytelnika budzi to, że "Gorąco pragnął sensu i w więzieniu i na wolności", jak pisał przed laty w jednym $z$ fundamentalnych dla watologii tekstów Klemens Szaniawski ${ }^{14}$. Baron-Milian tekstu Szaniawskiego chyba nie zna, przynamniej nie odnotowuje go w bibliografii, co gorsza, wątek niezwykłości stalinizmu i ściśle z nim związany, a kluczowy dla Wata wątek odkrywania/budowania nie-zwykłości własnego doświadczenia życiowego w ogóle pomija, trudno nawet powiedzieć, czy go dostrzega, przenosząc w zamian na bohatera swojej książki własną skłonność do efektownych generalizacji. Nie sposób oprzeć się wrażeniu, że bardziej niż życiowe doświadczenie Wata i podejmowane przez niego próby jego opisu,

${ }^{13}$ Tak odsyłam do: A. Wat, Świat na haku i pod kluczem. Eseje, oprac. K. Rutkowski, Warszawa 1991.

${ }^{14} \mathrm{~K}$. Szaniawski, Metafizyka zniewolenia - świadectwo Aleksandra Wata, [w:] Literatura źle obecna (Rekonesans), Londyn 1984, s. 76. 
w całej ich indywidualności, oryginalności, osobliwości, idiomatyczności, Baron-Milian interesują własne koncepcje i koncepty.

Z cokolwiek groteskową wyrazistością widać to we fragmencie jej książki dotyczącym pobytu Wata w Berkeley. Autorka buduje tu całą dramatyczną opowieść: wyjazd do Berkeley miał dojść do skutku za cenę „licznych zobowiązań" (s. 194) wobec amerykańskich instytucji, „Wat w zamian za otrzymane stypendia i pomoc finansową zobowiązał się ukończyć kilka książek" (s. 197), jednak pogorszenie stanu zdrowia uniemożliwiło mu wypełnienie tych "zobowiązań, w efekcie dla żyjącego w poczuciu winy i długu Wata „Twórczy wysiłek staje się więc teraz wynikiem bezpośredniego ekonomicznego oraz moralnego nakazu i, jak można przypuszczać, pracę literacką, pisanie stopniowo zaczyna osłaniać mroczny cień alienacji" (s. 198), pisanie "przestaje wynikać z wewnętrznej potrzeby" staje się „chorobotwórcze" (s. 199). Przypadek Wata „w całej okazałości" ukazuje nam „nowoczesny podmiot, poddany opresji kapitału, pogrążony w permanentnym stanie »bycia winnym«" (s. 201), ujawnia "logikę kapitalizmu, który wprowadził podmiot w permanentny stan bycia winnym" (s. 202).

Cała ta dramatyczna opowieść mogła zostać skonstruowana jedynie za cenę zignorowania faktów. Choć Wat rzeczywiście w związku z pobytem w Berkeley używał retoryki „kredytu” (D 179 ${ }^{15}$ ), „zadłużenia”, nawet „haniebnego" (D 235), wyrażał w ten sposób własną frustrację, jaką wywołało fiasko szeroko zakrojonych planów pisarskich, z którymi jechał do Ameryki, i niezależnie od retoryki była to wyłącznie kwestia wewnętrznego poczucia moralnego zobowiązania. Natomiast, jak wiemy chociażby od Miłosza, który pisał o tym w przedmowie do Mojego wieku (MW I 13-14), a także od samego Wata, pobyt w Berkeley nie wiązał się z żadnymi zobowiązaniami zewnętrznymi i sformalizowanymi. Baron-Milian nawet cytuje fragment z Kartek na wietrze, gdzie o tym mowa (D 314, zob. s. 195), ale po prostu nie przyjmuje tego do wiadomości: „wewnętrzny charakter przymusu zdaje się jednak tylko pozorny, $\mathrm{w}$ gruncie rzeczy mamy tu przecież do czynienia z zewnętrznym, nałożonym arbitralnie przez wspólnotę zobowiązaniem" (s. 198). Nie jest też tak, że kłopoty Wata z pisaniem rozpoczęły się w okresie pobytu w Berkeley. Tu również wskazać można lekturę przez autorkę pominiętą: artykuł Germana Ritza, który pokazuje, że frustracja Wata-pisarza miała swoje źródła już w sytuacji z drugiej połowy lat 40., gdy po powrocie z Kazachstanu do Polski autor Bezrobotnego Lucyfera podjął „próbę nowego początku" działalności literackiej, próbę nieudaną, bo jego wysiłki nie przyniosły żadnych znaczących osiągnięć ${ }^{16}$.

I jeszcze jeden przykład dezinterpretacji, który, nie będę ukrywał, szczególnie mnie w trakcie lektury książki Marty Baron-Milian zbulwersował. Na stronie 137 autorka cytuje fragment "pamiętnika mówionego" dotyczący dramatycznego okresu, gdy Watowie, zmuszeni do opuszczenia

${ }^{15}$ Tak odsyłam do: A. Wat, Dziennik bez samogłosek, oprac. Ki P. Pietrychowie, Warszawa 2001.

${ }^{16}$ G. Ritz, Aleksander Wat - próba ponownego początku po roku 1946, „Twórczość” $2001 \mathrm{nr} 4$. Rozległą argumentację uzasadniającą tezy Ritza daję w książce Aleksander Wat w Polsce powojennej (1946-1953). Teksty i konteksty (Kielce 2011), której także Baron-Milian, jak wynika $\mathrm{z}$ bibliografii, nie zna. 
Ałma Aty po likwidacji polskiej delegatury, żyli w szczególnie trudnych warunkach w niewielkiej miejscowości Ilia na kazachskiej prowincji:

nie mieliśmy najmniejszego zmysłu do handlu. $\mathrm{W}$ jedynym ${ }^{17}$ wypadku, gdy próbowałem coś przehandlować, raczej na tym straciłem. Więc ani ja, ani Ola zupełnie nie nadawaliśmy się do tego. Gdy Żyd nie ma zdolności do handlu, to jest okropne. Handel i spekulacja to była jedyna możliwość, aby wyżyć przez te trzy i pół roku... (MW II, s. 337)

\section{Komentarz Baron-Milian:}

Dokładnie na tle całej tej rodzinnej opowieści będzie się rozwijać w twórczości Wata zaangażowana i nieustępliwa krytyka mechanizmów wolnorynkowych (s. 137).

Tu można by autorce polecić uważniejszą lekturę książek... Aleksandra Wata, bo to już nie jest jakieś misreading, to czytanie bez elementarnej empatii i po prostu bez zrozumienia.

Do przywołanego fragmentu Mojego wieku trzeba podejść z pewnym dystansem, uwzględniając kontekst: Wat daje jednoznaczną negatywną ocenę umiejętności handlowych swoich i żony, aby na tym tle uwypuklić szlachetność postawy innych przesiedleńców, Żydów polskich, wśród których przyszło im żyć w Ili i dzięki życzliwości których, mimo demonstrowanej wtedy przez Aleksandra konwersji religijnej na katolicyzm, Watowie byli w stanie przeżyć $\mathrm{w}$ warunkach skrajnej nędzy; warto jednocześnie zauważyć, że niewielkie doświadczenie Watów w handlowaniu, a co za tym idzie, ich niewielkie umiejętności $w$ tym względzie, brały się $w$ niemałym zapewne stopniu z tego, że żyjąc $w$ skrajnej nędzy po prostu nie mieli czym handlować. Być może ,jedyny wypadek”, który miał Wat na myśli w cytowanym fragmencie Mojego wieku to epizod z maja 1944 roku, gdy zasłabł na tołkuczce w Ałma Acie. Było to dla niego wydarzenie pamiętne, do którego niejednokrotnie potem powracał (najpełniejszy opis zob. D 226-228), bo traktował je jako doświadczenie umierania, ale nie mniej poruszające są realia z tym wydarzeniem związane: Wat, niewyleczony jeszcze po tyfusie, udaje się 80 kilometrów z Ili do Ałma Aty, aby spróbować sprzedać dwa koce, „które cudowną łaską losu nadeszły właśnie z Iranu”, bo była to jedyna możliwość, aby zaradzić sytuacji, gdy „w domu nie było nic do jedzenia". Potraktowanie, w takim kontekście, doświadczenia związanego z próbą handlowania na tołkuczce, którą można uznać za pozostałość „mechanizmów wolnorynkowych" w państwie Stalina, jako doświadczenia skłaniającego Wata do krytyki tychże "mechanizmów”, jest po prostu absurdalne. Stwierdzenie Wata „Handel i spekulacja to była jedyna możliwość, aby wyżyć" można i, co więcej, trzeba czytać dosłownie. Opresyjność stalinowskiego państwa, której Watowie doświadczyli na zesłaniu, skłaniała do

${ }^{17}$ Poprawiam tu za Moim wiekiem Wata literówkę, która wkradła się do książki Baron-Milian, gdzie jest ,jednym". 
„zaangażowanej i nieustępliwej krytyki”, ale nie - „mechanizmów wolnorynkowych", tylko ustroju, który powołując się na marksistowską ideologię owe mechanizmy oficjalnie odrzucił przejmując pełną kontrolę nad gospodarką, co w praktyce oznaczało skazanie i przeciwników politycznych, jeżeli za takich uznać przymusowych przesiedleńców, i własnych obywateli na skrajną niekiedy nędzę.

Komentarz Baron-Milian jest nie tylko absolutnie nietrafny, jest po prostu doktrynerski. Objawia się tu cecha książki Wat plus Vat najbardziej kontrowersyjna, choć też w pewnym sensie najciekawsza, uzasadniająca dokładną analizę osobliwości tej budzącej tyle zastrzeżeń publikacji.

Wydaje się, że można mówić o doktrynerstwie Baron-Milian i to bez cudzysłowu, o czym przesądza, dodam dla jasności, oczywiście nie sam fakt, że jej sympatię budzi „krytyka marksistowska” i idee z kręgu Nowej Lewicy, ale to, co ta sympatia, „marksizm” autorki, oznacza w praktyce. A oznacza, że z jednej strony wykazywanie w twórczości Wata "dyktanda” systemu ekonomicznego dokonuje się nierzadko na zasadzie nadinterpretacji, czy nawet dezinterpretacji jego tekstów, z drugiej strony zaś sprowadza się do tropienia złowrogiego oddziaływania "mechanizmów wolnorynkowych" i „logiki kapitalizmu”; dopowiedzieć też tu trzeba, że „ekonomia” w jej wymiarze ekonomii politycznej to dla Baron-Miliana jednoznacznie i wyłącznie ekonomia kapitalizmu. Podstawą tezą jej książki jest twierdzenie, że począwszy od Bezrobotnego Lucyfera najważniejszym tematem twórczości Wata na wszystkich jej poziomach stało się „potworne oblicze” nowoczesnego kapitalizmu (s. 94), że Wat próbował budować w swoich utworach „przestrzeni oporu wobec systemu kapitalistycznego, wobec idei wolnego rynku” i „nigdy nie przestaje być jednak utopistą, snującym marzenie o życiu poza logiką rynku, poza ekonomicznym terytorium, w którym zupełnie nie może się odnaleźć, które go przytłacza, i zgodnie ze swą naturą wpędza w stan zadłużenia, generując stale pogłębiające się poczucie winy" (s. 28).

Książka Baron-Milian może stanowić dowód na odżywanie tendencji marksizujących w polskim dyskursie akademickim. Dowód to jednak o tyle dwuznaczny, że zastosowany do Wata "marksizm” autorki ulega autokompromitacji.

Jedną z przyczyn jest zaskakująca powierzchowność i trywialność tego „marksizmu”. Dobrze to widać, gdy zestawić książkę polskiej badaczki z pisarstwem Marshalla Bermana, na którego Baron-Milian się powołuje. Berman dokonał oryginalnej reinterpretacji dzieła Marksa pokazując go nie tylko jako analityka rzeczywistości ekonomicznej, modernizacji w gospodarce, ale i jako wielkiego modernistycznego pisarza, w którego tekstach pojawiają się kluczowa idea modernizmu, którą do europejskiej kultury wprowadziła burżuazja - odczarowania świata, idea otwierająca nieograniczone perspektywy, ale przynosząca jednocześnie dojmujące poczucie braku bezpieczeństwa; to tę ideę Berman zaakcentował cytatem z Manifestu komunistycznego w tytule najważniejszej swojej książki: „wszystko, co stałe, rozpływa się w powietrzu". Jak podkreśla Agata Bielik-Robson, oryginalność reinterpretacji Bermana polega miedzy innymi na tym, że pokazuje on daleki od jednoznaczności stosunek Marksa do burżuazji, pełen 
niechęci, ale i fascynacji, a także na tym, że Berman nie sprowadzał marksizmu do ekonomii politycznej ${ }^{18}$. Baron-Milian, choć się na Bermana powołuje, również amerykańskiego marksistę czyta w upraszczający sposób (zob. s. 110-111), bo jednak bliżej jej do, jak to określa Bielik-Robson, marksistów „redukcyjnie myślących"19. Mimo werbalnej akceptacji wizji „płynnej nowoczesności", w opisach rzeczywistości ekonomicznej Baron-Milian wyraźnie ciąży ku ujęciom marksizmu „redukcyjnego”, gdzie „wolny rynek” i „kapitał” są jednoznacznie negatywnymi bohaterami i nawet kryzysy gospodarcze „leżą w interesie klas panujących”. To ostatnie określenie, mimo że pojawia się w komentarzu do Bermana, nie ma z nim nic wspólnego, może natomiast starszym czytelnikom książki Wat plus Vat przypominać odległą już przeszłość - frazesy peerelowskiej nowomowy, do czego jeszcze powrócę. Na razie chciałbym odnotować jeszcze jedną różnicę między autorem książki „Wszystko, co stałe, rozptywa się w powietrzu” a autorką książki Wat plus Vat: Bermanowi, który jednym z kluczowych wątków uczynił obraz wielkomiejskiej ulicy pojawiający się u wielkich pisarzy XIX i XX wieku, których czyta wnikliwie i z ujmującą empatią, zapewne nie przytrafiłoby się tak dezinterpretujące ujęcie doświadczeń Wata z okresu zesłania w Kazachstanie, tak jak nie dziwiłby się zapewne, po uwzględnieniu życiowych doświadczeń Wata, że potrafi on docenić rzeczywistość społeczną i polityczną kapitalistycznych państw Zachodu (ŚNH 59), co zaskakuje Baron-Milian jako niezrozumiała właściwie niekonsekwencja: „Wolta, którą wykonała formułowana przez Wata na przestrzeni lat diagnoza kultury, cywilizacji, społeczeństwa, ekonomii, polityki jest doprawdy zaskakująca" (s. 114).

To zaskoczenie autorki sygnalizuje najbardziej rzeczywiście zaskakującą cechę jej postawy: mimo opowiadania się po stronie „metody historycznej" wykazuje się ona zdumiewająco słabym zmysłem historycznym, wyczuciem historycznych realiów i kontekstów. Choć to zapewne nie tylko cecha postawy badawczej Baron-Milian, ale i signum temporis.

Dla autora Mojego wieku i dla jego czytelników w latach siedemdziesiątych i osiemdziesiątych, gdy „pamiętnik mówiony” był drugoobiegowym „bestsellerem" opozycyjnych kręgów inteligencji ${ }^{20}$, nie ulegało wątpliwości, że to doświadczenie komunizmu i stalinizmu jest w biografii i twórczości Wata najważniejsze. Jak nie bez egzaltacji stwierdzał Miłosz w trakcie rozmów z Watem:

Nie wiem, czy zdajesz sobie sprawę, że nasze rozmowy nie są zbieraniem materiałów dla historyka naszego stulecia, ale rozmawiając z tobą mam absolutne poczucie wagi tych rzeczy dla ludzi za lat dwieście. Naprawdę! My rozmawiamy o rzeczach, które mają ogromną wagę w historii gatunku

${ }^{18}$ A. Bielik-Robson, Życie i cała reszta: Marshalla Bermana marksizm romantyczny, [wstęp w:] M. Berman, "Wszystko, co stałe, rozptywa się w powietrzu”. Rzecz o doświadczeniu nowoczesności, przeł. M. Szuster, Kraków 2006, s. VI.

${ }^{19}$ Zob. tamże.

${ }^{20} \mathrm{O}$ Moim wieku jako „bestsellerze lat osiemdziesiątych” pisała Małgorzata Baranowska w świetnym szkicu Aleksander Wat: choroba wieku, [w:] Sporne postaci polskiej literatury wspótczesnej, red. A. Brodzka, Warszawa 1994. Nb. to jeden z tych ważnych w watologii tekstów, których nie ma w bibliografii Baron-Milian. 
ludzkiego, ale nie w kategoriach jakichś: komunizm, antykomunizm, tylko naprawdę przyszłości (MW I 156).

Dziś to oczywiste, że Miłosz, sam Wat i jego czytelnicy „drugoobiegowi” nie mieli racji. Jak się okazało, wystarczyło 25 lat od momentu, gdy Miłosz formułował swoją przepowiednię, aby po przemianach politycznych 1989 roku w znaczącym stopniu zmniejszyła się aktualność doświadczeń Wata, związanych z zamkniętą już szczęśliwie przeszłością.

Książka Baron-Milian (rocznik 1985) dowodzi, że proces ten postępuje. Nawet - zdumiewająco daleko: doświadczenia Wata związane z komunizmem i stalinizmem są w tej książce właściwie nieobecne. Pojawiają się co prawda uwagi w rodzaju „O marksizmie Wata i późniejszej krytyce ustroju komunistycznego napisano bardzo wiele. Wątki te są także tłem wszystkich części niniejszych rozważań, a niejednokrotnie odgrywają w niech pierwszoplanową rolę." (s. 115), zaś przy nieszczęsnym artykule Keynesa Baron-Milian odnotowuje, cokolwiek eufemistycznie, ale jednak, że Wat czytał go, aby skonfrontować „wizje wolnorynkowej gospodarki i państwowego interwencjonizmu" (s. 120) - ale poza takie zdawkowe uwagi autorka nie wychodzi i nie ma w jej książce fragmentów, gdzie przeprowadzona przez Wata „krytyka ustroju komunistycznego” odgrywałaby „pierwszoplanową rolę". Jest w tym zresztą zasadnicza niekonsekwencja: skoro Wata cechować miała „nadzwyczajna predylekcja [...] do ekonomicznego czy materialistycznego sposobu myślenia o własnym życiu, rzeczywistości i literaturze", to takie jego nastawienie musiało się także objawiać w Moim wieku czy szkicach sowietologicznych pisanych w latach sześćdziesiątych Baron-Milian, choć wspomina nawet, że Wat dokonał „radykalnej krytyki marksistowskiej ekonomii" (s. 115), nie podejmuje żadnej próby, aby zrekonstruować Watowski opis ekonomii politycznej stalinizmu. Taka próba uchroniłaby ją nie tylko przed ewidentnym brakiem konsekwencji w stosunku do własnych założeń. Może także pozwoliłaby zapanować nad retoryczną maszynerią, która wytworzyła w zakończeniu książki rodzaj swoistego happy endu: wizję wspólnoty przełamującej „mechanizmy wolnorynkowe” za pomocą "daru”, pozwalającego zerwać z wymianą opartą na pieniądzu (zob. s. 267); jest to wizja słabo przez teksty Wata uzasadniona, poczynając od tego, że "dar" nie zawsze jest u niego, jak w Buchalterii, pojęciem pozytywnym i autorka pisząca o „ekonomii” koniecznie powinna zainteresować się stwierdzeniem Wata, że „ekonomia komunistyczna jest gospodarką opartą na stosunkach darów i przywilejów" (ŚNH 62).

To wszystko można Baron-Milian zarzucić. A także to, że jej dyskurs badawczy należy do tych, które powstają „w akademickich wieżach z kości słoniowej czy, jak kto woli, campusowych oblężonych twierdzach"21. To jest zarzut, ale i wyjaśnienie (choć nie - usprawiedliwienie). Z perspektywy „akademickich wież" zaciera się różnica między komunizmem zrealizowanym w państwie Stalina i kapitalizmem, skoro w obu przypadkach, to

${ }^{21}$ A. Bielik-Robson, Marks tańczący, s. 8; Bielik-Robson teoriom powstającym w takim oderwaniu od rzeczywistości przeciwstawia "sokratejską" twórczość Bermana wyrastającą z obserwacji „,znaków ulicy”. 
dla czytelnika Foucaulta oczywistość, mamy do czynienia z formą władzy, „każdej” władzy.

Dystans wynika jednak nie tylko z usytuowania dyskursu akademickiego w przestrzeni społecznej, buduje go także upływ czasu. Książka Baron-Milian uświadamia, że pewne skojarzenia, a nawet odruchy, dla Wata i jego pierwszych czytelników oczywiste, oczywiste już nie są (zwłaszcza że nie jest mocną stroną autorki skrupulatność w rekonstrukcji historycznych realiów i kontekstów). Tym tłumaczyć można owo poczucie peerelowskiego déjà vu przy lekturze książki, której autorka PRL-u już nie pamięta - i w której, paradoksalnie, PRL jest na poziomie tego, co bezpośrednio artykułowane, zdumiewająco konsekwentnie nieobecny jako temat czy choćby kontekst. Co prowadzi do sytuacji właściwie zabawnej: Baron-Milian ma kłopot z odpowiedzią na pytanie, dlaczego „zwłaszcza w Polsce” - sic! - badanie związków literatury z ekonomią nie cieszy się popularnością, istnieje wręcz "problem dyscyplinarnego oporu", i pytanie to jest dla autorki na tyle kłopotliwe, że musi aż uciekać się do Hörischa i jego opisu koniunkturalizmu intelektualistów... niemieckich (s. 14), nie pojawia się natomiast wyjaśnienie narzucające się, choć jak się okazuje, już nie wszystkim: postpeerelowski uraz badaczy literatury, zniechęcający do zajmowania się kwestiami i ujęciami przed przełomem politycznym 1989 roku oficjalnie preferowanymi.

Dla Baron-Milian nie jest już oczywiste, że nie można pisać o „zgniłym” kapitalizmie (zob. s. 91), bo ze względu na skojarzenia z językiem peerelowskiej propagandy brzmi to jak niezamierzona autoparodia. Nie warto też dopatrywać się szczególnych walorów w obrazie krwi wyciskanej z dolara (w wierszu Wata *** "Łapa, która ziemię nam marszczy" z 1948 roku), bo jest to klisza stalinowskiej propagandy antykapitalistycznej; jest skądinąd rzeczą ciekawą, dlatego Wat zaledwie kilkanaście miesięcy po powrocie z Kazachstanu gotów był sięgać po takie klisze, chociaż nie były to nawet jeszcze czasy socrealizmu, proklamowanego w polskiej literaturze rok później, ta kwestia jedna autorki książki Wat plus Vat nie interesuje.

Wróćmy więc do wątpliwości, jakie budzi „marksizm” Baron-Milian. Niechęć do „wolnego rynku” i „kapitału”, wyrazista retorycznie i niewątpliwa, choć cedowana na Wata, prowadzi ją do dwuznacznego dowartościowania odnajdywanych u autora Mojego wieku śladów komunistycznych ideałów czy po prostu propagandy. Tak jest właśnie w przypadku wiersza *** "Łapa, która ziemię nam marszczy": autorka zdaje sobie sprawę z tego, że jest to utwór "tendencyjny", związany z komunistyczną propagandą czasów zimnej wojny, ale nie może się powstrzymać od stwierdzenia, że w tym wierszu „,w sugestywny literacko sposób obnaża się jednak skryta natura pieniądza" (s. 101). Podobnie jako swoistą felix culpa traktuje zaangażowanie Wata-redaktora "Miesięcznika Literackiego" w marksistowską ortodoksję, skoro przyniosło "perełkę" powiązania metaforyki awangardowych poetów z inflacją (s. 81). Trudno oprzeć się w tym kontekście podejrzeniu, że właśnie ze względu na swój „marksizm” Baron-Milian pomija praktycznie milczeniem kwestię ekonomii politycznej stalinizmu, pomija także odniesienia do PRL-u - ich uwzględnienie niewątpliwie 
komplikowałoby prostą wizję świata, w której w roli czarnych charakterów występuje „wolny rynek”, "kapitał” i "pieniądz” (i to jednak raczej dolar, a nie na przykład rubel).

Baron-Milian nie dostrzega niestosowności $\mathrm{w}$ takiej reinterpretacji Wata, w której kwestia jego doświadczeń związanych z komunizmem i stalinizmem zostaje zmarginalizowana, a najważniejsza dla autora Bezrobotnego Lucyfera okazuje się krytyka kapitalizmu, nie dostrzega też dwuznaczności swoich zabiegów. W latach 80., gdy Mój wiek był drugoobiegowym bestsellerem ze względu na swoją antykomunistyczną wymowę, istnienie drugiego obiegu wpływało na obieg pierwszy, poddany peerelowskiej cenzurze, wymuszając pewną jego liberalizację, zaczęły się wtedy ukazywać oficjalnie, zwłaszcza w drugiej połowie dekady dzieła wcześniej przez cenzurę wyklęte i zabronione, z Dziełami Gombrowicza na czele. Otóż robi się trochę śmiesznie, trochę strasznie, gdy się pomyśli, że książka Wat plus Vat ze swoją marginalizacją, ale przecież już nie całkowitym przemilczeniem kwestii komunizmu i stalinizmu i z nadrzędną tezą o antykapitalistycznym nastawieniu autora Mojego wieku mogłaby ucieszyć peerelowskich decydentów od literatury, byłaby świetnym narzędziem oswajania głośnego, ale kontrowersyjnego przez swój antykomunizm pisarza, i mogłaby zostać w latach osiemdziesiątych wydana w obiegu oficjalnym.

Aby jednak nie kończyć w nastroju trochę śmiesznym, trochę strasznym, krytyczną oceną książki Marty Baron-Milian chciałbym wyrazić w sposób zapewne jej bliższy - po derridiańsku: choć autorka, usiłując zrobić z drugorzędnego motywu tekstów Wata ich motyw przewodni, obwieszcza swoją „inwencję" jako „odkrycie” (zob. s. 13), jej rozważania odwołujące się do mgliście rozumianej „ekonomii", okazują się ostatecznie „ekonomią tego samego": odnajdywaniem u Wata podobieństw do idei i konceptów obecnych $u$ cenionych przez autorkę ponowoczesnych pisarzy i budowaniem dyskursu podporządkowanego apriorycznej tezie o „nadzwyczajnej predylekcji pisarza do ekonomicznego czy materialistycznego sposobu myślenia o własnym życiu, rzeczywistości i literaturze".

I ostatnia już uwaga: pisząc o inflacji w latach dwudziestych XX wieku, Baron-Milian pchana retorycznym rozpędem pisze także o inflacji we współczesnej humanistyce, "inflacji dyskursu, tekstu, publikacji” (s. 40), opatrując jednak te dywagacje zastrzeżeniem wobec ukrytego między wierszami krytycznych diagnoz postulatu „przywrócenia jakiejś utopijnej symetrii między podażą i popytem, która w gruncie rzeczy nigdy w humanistyce nie istniała, bo jej istotą jest ta inflacyjna nadwyżka, którą w zakresie publikacji i refleksji stale musi wytwarzać, by nie utracić swej dynamiki, różnorodności i wielości perspektyw" (s. 41, przypis). Zastrzeżenie to wyjątkowo trafne, ale też trudno przypuścić, aby ktokolwiek, autorki książki Wat plus Vat nie wyłączając, pisał od razu zakładając, że efekt jego działań i ich wartość będzie można sprowadzić jedynie do przyrostu „inflacyjnej nadwyżki". A tak, jak nietrudno się domyśleć, postrzegam wartość książki Wat plus Vat. Choć jednocześnie, i to bodaj najbardziej optymistyczny rezultat, jaki może dać kontakt z tą książką, rodzi się w trakcie jej lektury podejrzenie, że wieści o inflacji w humanistyce są jednak przesadzone, że tej 
inflacji da się w jakimś przynamniej stopniu przeciwdziałać - dbając o podejście mniej aprioryczne i jednocześnie bardziej rzetelne do wybranych zagadnień, problemów, tekstów i ludzkich losów.

\section{B I B L I O G R A F I A}

Baranowska M., Aleksander Wat: choroba wieku, [w:] Sporne postaci polskiej literatury wspótczesnej, pod red. A. Brodzkiej, Warszawa 1994.

Baron-Milian M., Wat plus Vat. Zwiazzki literatury i ekonomii w twórczości Aleksandra Wata, Katowice 2015.

Berman M., "Wszystko, co stałe, rozptywa się w powietrzu”. Rzecz o doświadczeniu nowoczesności, przeł. M. Szuster, Kraków 2006.

Bielik-Robson A., Marks tańczacy, [przedmowa w:] M. Berman, Przygody z marksizmem, przeł. S. Szymański, Warszawa 2012.

Bielik-Robson A., Życie i cała reszta: Marshalla Bermana marksizm romantyczny, [wstęp w:] M. Berman, "Wszystko, co stałe, rozptywa się w powietrzu”. Rzecz o doświadczeniu nowoczesności, przeł. M. Szuster, Kraków 2006.

Bolecki W., Odmiany tekstu, [w:] A. Wat, Bezrobotny Lucyfer i inne opowieści, oprac. W. Bolecki i J. Zieliński, Warszawa 1993.

Derrida J., Psyché. Odkrywanie innego, przeł. M. P. Markowski, [w:] Postmodernizm. Antologia przekładów, oprac. R. Nycz, Kraków 1997, s. 104.

Hörisch J., Orzeł czy reszka. Poezja pieniadza, przeł. J. Kita-Huber, S. Huber, Kraków 2010, s. 325.

Leociak J., O nadużyciach w badaniach nad doświadczeniem Zagłady, "Zagłada Żydów. Studia i materiały" 2010, nr 6.

Pomirowski L., "Bezrobotny Lucyfer" Wata, „Wiadomości Literackie” 1927, nr 10, 6 III.

Ritz G., Aleksander Wat - próba ponownego początku po roku 1946, „Twórczość” $2001 \mathrm{nr} 4$.

Stownik języka polskiego, red. W. Doroszewski, Warszawa 1965, t. II D-G.

Szaniawski K., Metafizyka zniewolenia - świadectwo Aleksandra Wata, [w:] Literatura źle obecna (Rekonesans), Londyn 1984.

Wat A., Dziennik bez samogłosek, oprac. K i P. Pietrychowie, Warszawa 2001.

Wat A., Mój wiek. Pamiętnik mówiony, rozmowy prowadził i przedmową opatrzył Cz. Miłosz, do druku przygotowała L. Ciołkoszowa, przypisy opracował R. Habielski, Warszawa 1998, t. I-II.

Wat A., Notatniki, oprac. A. Dziadek, J. Zieliński, Warszawa 2015.

Wat A., Publicystyka, oprac. P. Pietrych, Warszawa 2008.

Wat A., Świat na haku i pod kluczem. Eseje, oprac. K. Rutkowski, Warszawa 1991. 


\section{STRESZCZENIE}

Tytuł książki Marty Baron-Milian Wat plus Vat. Związki literatury i ekonomii w twórczości Aleksandra Wata wprowadza sugestię, że mamy do czynienia z oryginalnym ujęciem utworów autora Mojego wieku, ale czytelnika tej pracy czeka niemiłe rozczarowanie. Autorka, niewątpliwie oczytana w autorytetach współczesnej humanistyki, sprawnie posługuje się jej instrumentarium pojęciowym, natomiast teksty samego Wata interpretuje w sposób dyskusyjny, nieprzekonujący i nierzadko po prostu dowolny, z zadziwiającą i trudną do przyjęcia dezynwolturą traktuje bowiem ich historyczne i historycznoliterackie konteksty, podporządkowując swoje odczytania apriorycznie przyjętym tezom. Baron-Milian daje w swojej książce wyrazisty, choć zapewne mimowolny, przykład retorycznej „inflacji” we współczesnej humanistyce.

\section{Słowa kluczowe}

Aleksander Wat, literatura a ekonomia, humanistyka współczesna

\section{S U M M A RY}

\section{Wat plus inflation (in humanities)}

Even if the title of Marta Baron-Milian's book - Wat Plus VAT. Relationships between Literature and Economy in the works by Aleksander Wat (Wat plus Vat. Zwiazki literatury i ekonomii w twórczości Aleksandra Wata) - implies that the publication offers an overtly original approach to the works by the man responsible for such masterpieces as My Century (Mój wiek), the reader will be quite bitterly disappointed. Undoubtedly, Baron-Milian is well-read as far as authorities of the modern humanities are concerned, and she skilfully operates its glossary of terms. Her interpretations of Wat's works, however, tend to be questionable and unconvincing in nature, and quite often just arbitrary, since she approaches their historical and literary contexts with an astonishing and hardly acceptable flippancy, subordinating her interpretations to the theses accepted a priori. In her book, Baron-Milian provides a distinct and yet probably unintentional example of rhetoric 'inflation' within the modern humanities.

\section{Keywords}

Aleksander Wat, literature and economy, modern humanities 